\title{
Penetration-Type Microelectrode Array with a Silicone-Rubber Substrate
}

\author{
Jun Suzurikawa Non-member (The University of Tokyo, suzuri@brain.imi.i.u-tokyo.ac.jp) \\ Masayuki Nakao Member (The University of Tokyo, nakao@hnl.t.u-tokyo.ac.jp) \\ Hirokazu Takahashi Member (The University of Tokyo, takahashi@ i.u-tokyo.ac.jp)
}

Keywords : microelectrode array, flexible substrate, silicone rubber, electrophysiology, rat

Conventional electrode arrays for electrophysiological recording in cortex have substrates with stiff material, such as epoxy resin, silicon, and printed-circuit board. With such arrays, we cannot keep penetration depth of each electrode constant because of brain curvature. To overcome this problem, this paper proposes a penetration-type tungsten microelectrode array on a flexible silicone rubber substrate for neural recording. Our evaluation experiments confirmed that the flexible substrate keeps the penetration depth of each electrode constant and allows simultaneous multipoint recording of spike potentials from a desired neocortical layer.

In Fig. 1, design of the proposed electrode array is shown. The flexible silicone substrate curves along brain surface and keeps penetration depth of each electrode constant. Photographs of the prototyped array are shown in Fig. 2. By clipping the tungsten electrodes with a holder, as shown in Fig. 2(c), we can attach the array to a micromanipulator. This is an advantage in precision positioning of penetration sites, as compared with previous flexible arrays which were handled manually using tweezers.

We penetrated the present flexible array and a stiff array into agarose, which has a curvature comparable to that of the rat brain, and compared penetration depth (Fig. 3). The penetration depth of the flexible array was approximately constant across the electrodes (ANOVA, $p=0.835$ ), while that of the stiff array had a significant fluctuation (ANOVA, $\mathrm{p}<0.01$ ). The electrodes at the edge of the stiff array had up to $150 \mu \mathrm{m}$ error in its penetration depth as compared with that of the flexible array (t-test, $\mathrm{p}<0.01$ ). This result confirmed the availability of the silicone rubber substrate for targeting a desired depth.

Electrophysiological experiments in the rat auditory cortex

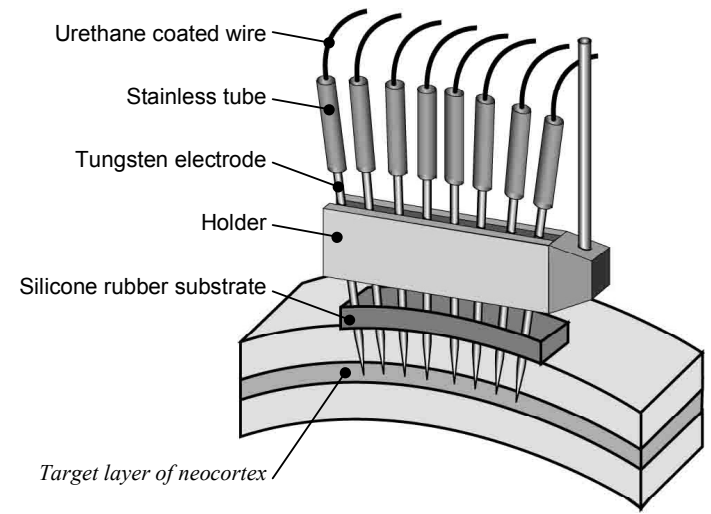

Fig. 1. Design of the proposed microelectrode array demonstrated that the simultaneous multipoint recording of the acoustically evoked spike potentials was feasible with the flexible array. A series of penetration trials and characteristic frequency estimations successfully identified the primary auditory cortex by assuring a gradual increase in the characteristic frequencies from caudal to rostral. This result suggests that the proposed electrode is suitable for acute experiments requiring repeated penetration and precision positioning of penetration sites.

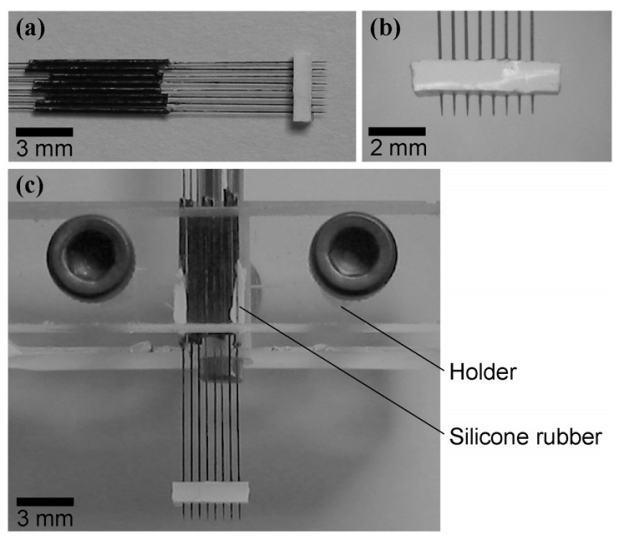

Fig. 2. Prototyped microelectrode array. (a)Whole view. (b)Tip magnification. (c)Array attached to the jig

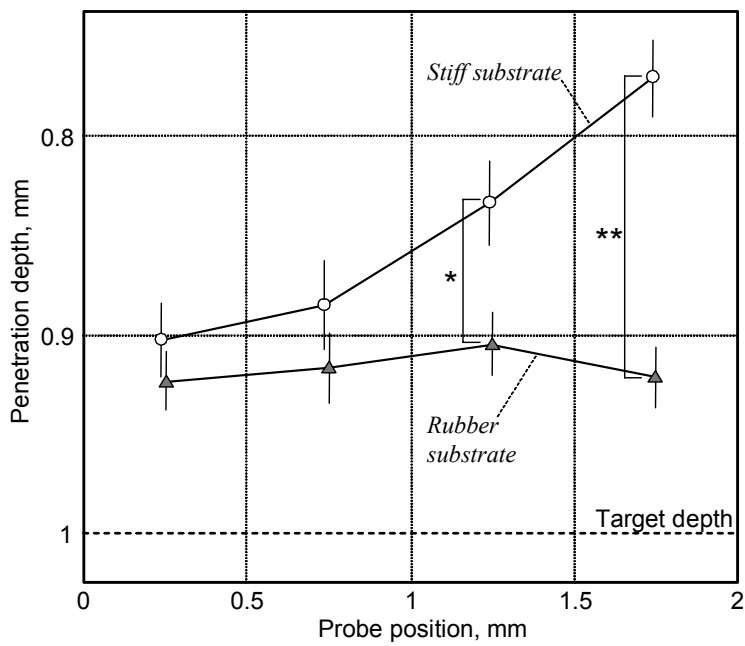

Fig. 3. Penetration depth of each electrode $(n=18)$. Means \pm SEs are plotted with respect to each kind of substrate against the electrode positions with a center of array as origin. *, $\mathrm{p}<0.05 ;{ }^{* *}, \mathrm{p}<0.01$; t-test 


\title{
シリコーンゴム基板を有する
}

\section{刺入型微小タングステン電極アレイの開発}

\author{
非会員 硯川 潤* 正 員 中尾 政之** \\ 正員 高橋 宏知*
}

\section{Penetration-Type Microelectrode Array with a Silicone-Rubber Substrate}

Jun Suzurikawa*, Non-member, Masayuki Nakao**, Member, Hirokazu Takahashi*, Member

This paper proposes a penetration-type tungsten microelectrode array on a flexible silicone rubber substrate for neural recording from a desired cortical layer. Our evaluation experiments confirmed that the flexible substrate keeps the penetration depth of each electrode constant and allows simultaneous multipoint recording of spike potentials from a desired neocortical layer. Penetration of the stiff and flexible arrays into agarose, which has the curvature comparable to that of the rat brain, revealed that the electrodes at the edge of the stiff array had up to $150 \mu \mathrm{m}$ error in its penetration depth, while the penetration depth of the flexible array was approximately constant across the electrodes (ANOVA, $\mathrm{p}=0.835$ ). Electrophysiological experiments in the rat auditory cortex demonstrated that the simultaneous multipoint recording of the acoustically evoked spike potentials was feasible with the flexible array. A series of penetration trials and characteristic frequency estimations successfully identified the primary auditory cortex by assuring a gradual increase in the characteristic frequencies from caudal to rostral. This result suggests that the proposed electrode is suitable for acute experiments requiring repeated penetration and precision positioning of penetration sites.

キーワード : 微小電極アレイ, 柔軟基板, シリコーンゴム, 電気生理, ラット

Keywords : microelectrode array, flexible substrate, silicone rubber, electrophysiology, rat

\section{1. はじめに}

大脳新皮質は 6 層から成る層構造を有しており，各層は それぞれ異なる役割を担っている。そのため，大脳新皮質 の神経回路の機能構造を詳細に調べるためには, 電極の刺 入位置に加え, 刺入深さを $10 \mu \mathrm{m}$ オーダで正確に制御して, 所望の層を選択的に計測・刺激する必要がある(1) (6)。従来, 大脳皮質での電気生理計測では，マイクロマニピュレータ に取り付けた単一微小電極を用いて，位置と深さを精密に 制御しながら刺入・計測を繰り返し, 二次元的な脳機能マ ップを得る手法が一般的であった ${ }^{(1)}$ 。しかし, 近年では微細 加工技術の発展と共に, 数本〜数百本の微小電極を基板に 配列した微小電極アレイが広く用いられるようになっ

* 東京大学大学院情報理工学系研究科

干153-8904 東京都目黒区駒場 4-6-1

Graduate School of Information Science and Technology, The University of Tokyo

4-6-1 Komaba, Meguro-ku, Tokyo 153-8904

** 東京大学大学院工学系研究科

T113-8656 東京都文京区本郷 7-3-1

Graduate School of Engineering, The University of Tokyo

7-3-1 Hongo, Bunkyo-ku, Tokyo 113-8656
た (7) (9)。一定間隔で固定された複数の電極から反応を同時 計測することで, 計測に必要な面積当りの時間を大幅に短 縮できる。しかし，これらの電極アレイの大半は，シリコ ン単結晶 ${ }^{(7)}$, エポキシ樹脂 ${ }^{(8)}$, プリント配線基板 ${ }^{(9)}$ など, 剛 性の高い基板を有するため, アレイ全体が曲率のある脳表 の形状に追従できず，各電極の刺入深さにばらつきが生じ るという問題があった。

この問題を解決するために, 脳表に沿って変形できる柔 軟なポリイミドフィルムを基板として用いた刺入型電極ア レイがこれまでに開発されてきた(10)(11)。しかし，これら の電極アレイは, 慢性埋め込み時に生体組織へ与える損傷 を低減することや軟組織の動きに追従することを主目的に 設計されているため, 一般的な急性実験での使用には不向 きな点が多い。急性実験では, 通常所望の部位を同定する ために, マイクロマニピュレータで刺入部位を正確に位置 決めしながら数回の刺入を繰り返し, アレイをマニピュレ ータで把持したまま神経反応を計測する。そのため, 電極 基板が柔軟であっても, マニピュレータに固定するための 把持部が不可欠であり，各電極は複数回の刺入に十分耐え 
られる材質であることが望ましい。

そこで本研究では古典的なタングステン電極 ${ }^{(12)(13)}$ と柔軟 なシリコーンゴム基板を用いて，マイクロマニピュレータ を用いた正確な位置決め・刺入が可能で，基板が脳表の形 状に追従して変形できる電極アレイを設計・試作・評価す る。

\section{2. 電極アレイの設計・試作}

〈2·1〉電極アレイの設計 図 1 に, 提案する電極ア

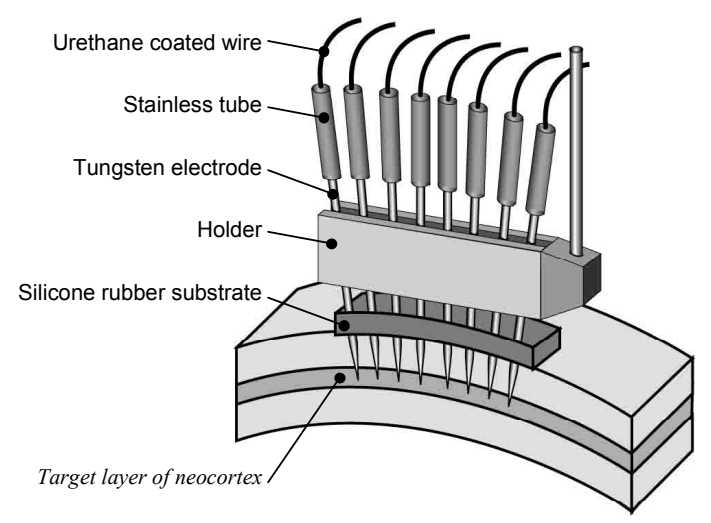

Fig. 1. Design of the proposed microelectrode array
レイの概念図を示す。本アレイには i) マニピュレータに取 り付けて皮質に繰り返し刺入できること, ii) 脳表の曲率に 追従して変形することがそれぞれ求められる。これらの要 求機能を満たすために，アレイは i) 一列に配列された微小 タングステン電極と，ii）それらを保持する柔軟なシリコー ンゴム基板とから成る。両端のタングステン電極を把持し てアレイを刺入すると, シリコーンゴム基板が脳表の形状 に追従して変形し, 各電極の刺入深さはばらつきなく一定 に保たれる。このとき, 刺入深さはゴム基板から突出した 電極の長さで決まるため, 対象とする動物種や層に応じて 製作時に設定する必要がある。シリコーンゴム基板の柔軟 性を損なわずにアレイを外部装置へ接続するために，各電 極はコネクタに直結されず，ウレタン皮膜線を介して接続 される。ステンレスチューブをウレタン皮膜線とタングス テン電極間のカップリングとして用いることで，特殊な治 具やワイヤボンダ等を用いることなく手作業で容易に配線 できる。

〈2·2〉製作工程 図 2 に示したように，製作工程は， アセンブリ型の製作 [図 2 (a)]・微小タングステン電極の製 作 [図 2(b)]・アセンブリ [図 2(c)] ・先端仕上げ [図 2(d)]・ 配線 [図 2(e)] の 5 工程から成る。アセンブリ型はアレイの 仕様を変更しない限り何度でも再利用できるため, 通常は (b)〜(e)の工程のみでアレイを製作できる。以下に，各工程

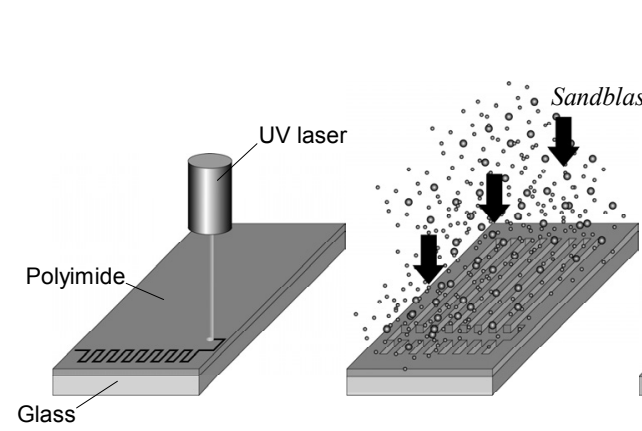

(a)

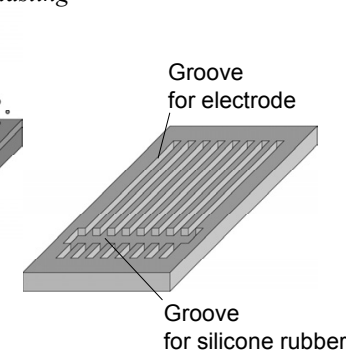

for silicone rubber

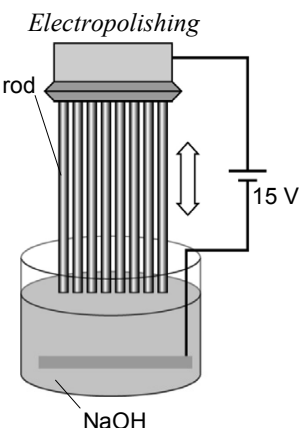

$\mathrm{NaOH}$

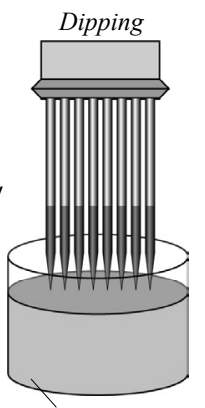

Cashew paint

(b)

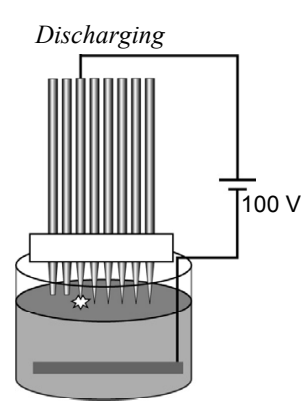

(d)

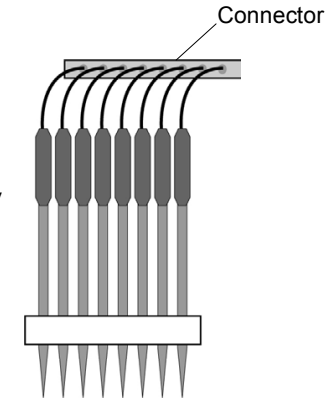

(e)

(a) Fabrication of an assembly mold. (b) Fabrication of tungsten microelectrodes. (c) Assembly of an array. (d) Tip processing. (e) Wiring.

Fig. 2. Process flow of the microelectrode array 


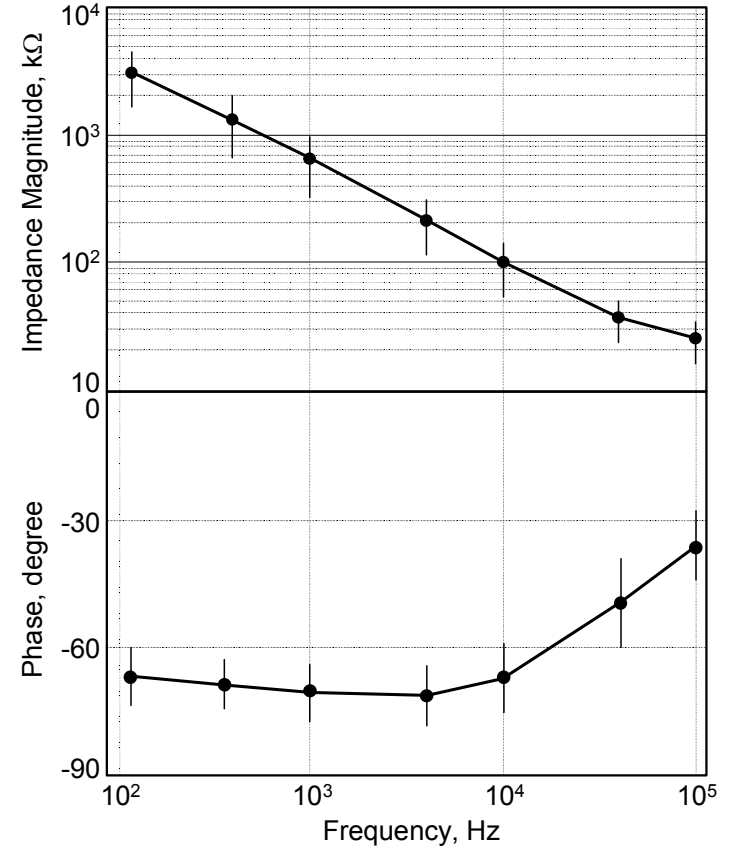

Fig. 3. Impedance spectroscopy of the tungsten microelectrodes $(\mathrm{n}=8)$

の詳細を述べる。

(a) アセンブリ型の製作 : アセンブリ型は，ガラス基板上 に成形され，タングステン電極を整列させるための溝（以 下，電極溝と呼ぶ）と，シリコーンゴム基板を成形するた めの溝（以下，基板溝と呼ぶ）とから成る。スライドガラ ス（松波硝子工業, S-1214）にポリイミドテープ（住友 $3 \mathrm{M}$, \#5412）を貼り，同テープを紫外線レーザ（東芝メカトロニ クス, LAY-617F）で溝の形状に切り抜いた。次に, それをマ スクとして, サンドブラスト加工機（ソニー, HJ-1500）で溝 を成形した。電極溝と基板溝の形状を調節することで，電 極アレイの電極本数・電極ピッチ・刺入深さ・基板厚・基 板幅をそれぞれ所望の值に設定できる。本研究では，電極 本数 8 本, 電極ピッチ $500 \mu \mathrm{m}$, 刺入深さ $1 \mathrm{~mm}$ とした。ま た, 基板厚を $1 \mathrm{~mm}$, 幅を 0.5-1 mm とした。なお, サンドブ ラスト加工で成形できる溝形状のアスペクト比は 1 程度で あるため，電極ピッチは最小で電極径のおよそ 2 倍に設定 できる。

(b) 微小タングステン電極の製作 : 微小タングステン電極 には，タングステンロッドを母材として用い，電解研磨で その先端を鋭利に成形した ${ }^{(14)}$ 。直径 $100 \mu \mathrm{m}$ のタングステン ロッド（ナリシゲ, E-3A）を微動ステージ（中央精機, MINI-40X）に取り付け， $1 \mathrm{mM}$ の水酸化ナトリウム水溶液 に浸した白金電極との間に $15 \mathrm{~V}$ の電圧をかけながら，上下 に 3 往復させ, 先端径 $10 \mu \mathrm{m}$ 程度まで研磨した。微動ステ ージは PC 駆動ドライバ（シグマ光機, MINI-10P）を用いて 速度 $60 \mu \mathrm{m} / \mathrm{s}$, ストローク $5 \mathrm{~mm}$ で上下させた。最後に, 成 形したタングステンの表面に，ディップ法でカシュー (Cashew Co., Ltd., Cashew Strone Paint) を塗布し, 電極全体を
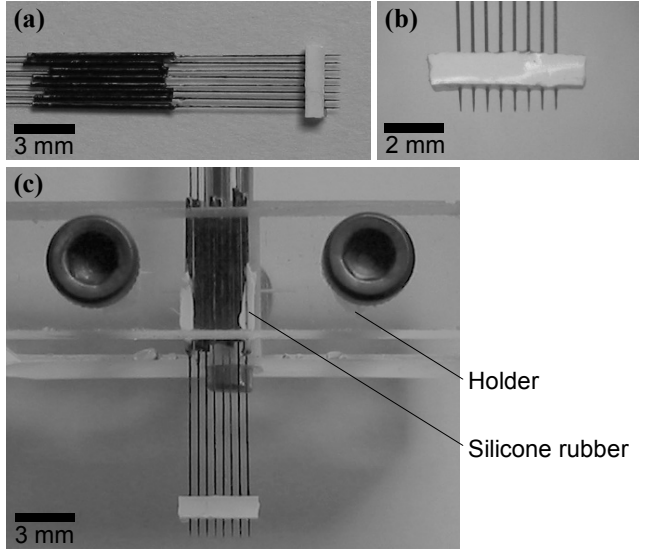

(a) Whole view. (b) Magnified view of electrode tips. (c) An array attached to a holder.

Fig. 4. Prototyped microelectrode array

絶縁した。

(c) アセンブリ：アセンブリ型の電極溝にタングステン電 極を配置し, 基板溝へ 2 液硬化形液状シリコーンゴム（GE 東芝シリコーン，TSE3504）を注入・硬化させ，電極アレイ を組み立てた。液状シリコーンゴムの流入を防ぐために, 電極溝はタングステン電極の配置後にカバーガラスで覆つ た。また，アレイの離型を容易にするために，アセンブリ 型にはシリコーンオイル（信越シリコーン, KF412SP）を離 型材としてあらかじめ塗布した。

(d) 先端仕上げ : アレイを離型した後, 電極の先端と絶縁 膜を放電で除去し，計測点を露出させた。先端のテーパ部 を水酸化ナトリウム水溶液に浸し, 電極と溶液中の白金電 極との間に $100 \mathrm{~V}$ 程度の電圧を印加して放電させた。このと き, 高倍率 CCD カメラ (キーエンス, VH-5910) で電極先端 を観察しながら, マイクロマニピュレータで先端が溶液中 に没する長さを制御することで，先端径を所望の值に調節 できる。先端径 $20 \mu \mathrm{m}$ に成形した微小タングステン電極の インピーダンスを図 3 に示す。 $1 \mathrm{kHz}$ の周波数でインピーダ ンスの大きさと位相はそれぞれ $646 \mathrm{kHz} ・-70^{\circ}$ だった。

(e) 配線 : 外径 $450 \mu \mathrm{m}$ ・内径 $230 \mu \mathrm{m}$ のステンレスチュー ブと直径 $100 \mu \mathrm{m}$ •線径 $80 \mu \mathrm{m}$ のウレタン皮膜銅線を介して, アレイをコネクタに接続した。ウレタン皮膜線をステンレ スチューブの一方に挿入し, 反対側から電極を挿入した。 ステンレスチューブと電極及びウレタン皮膜線との接続に は導電性エポキシ接着剤 (ITW Chemtronics, CW2400) を用 いた。また，隣接する電極同士の導通を防ぐために，ステ ンレスチューブにカシューを塗布して絶縁した。

〈2·3〉 ホルダと刺入方法＼cjkstart試作したアレイの概観を 図 4(a) に, その先端部の拡大写真を図 4(b) にそれぞれ示 す。図 4(c) に示したように, アレイは, シリコーンゴムを 塗布した両端の電極をホルダに挟んで使用する。両端のみ の電極を把持することで，アレイ全体は脳表の曲率に追従 して変形できる。なお，ステンレスチューブが電極の横方 
向への動きを拘束するため，電極同士の平行度は刺入時に も保たれる。

\section{3. 電極アレイの評価}

〈3·1〉 評価方法＼cjkstart試作した電極アレイの有用性を示 すために，アレイが曲率のある形状に追従して変形し，各 電極の刺入深さが一定に保たれることをアガロースへの刺 入実験で検証した。また，通常の電気生理実験では，ラッ 卜聴皮質の神経活動の計測を試みた。

まず，アレイを曲率のあるアガロース表面に刺入し，各 電極の刺入深さが一定になることを確認した。図 5(a) に実 験の概要を示す。基板の形状・硬さが刺入深さに与える影 響を調べるために，ゴム基板の奥行き幅がそれぞれ $0.5 ， 1$ $\mathrm{mm}$ の電極アレイと, 全ての電極をゴム基板の上部でステン レス板に接着固定したアレイ（以下固定アレイと呼ぶ）を 用いた。ラットの脳と同程度に，15 mm の曲率半径を持た せて成形したアガロース（ニッポンジーン, AgaroseS）に， マイクロマニュピレータで電極アレイを刺入し，アガロー ス表面から各電極先端までを刺入深さとして測定した。ア ガロースは生理食塩水中に濃度 $0.5 \mathrm{wt} \%$ で溶解させ，硬化時 にフェノールフタレイン溶液を混入させた。電極に通電す ると, 先端の電気分解でフェノールフタレインが赤色に変 色し，アレイ除去後も先端位置を確認できる。なお，硬化 させたアガロースに, 直径 $6 \mathrm{~mm}$ の圧力センサ（共和電業,
PS-05KD）を押し当てたときの圧力-変位係数は $1.2 \mathrm{kPa} / \mathrm{mm}$ で, ラットの大脳で実測した值 $(1.5 \mathrm{kPa} / \mathrm{mm})$ とよく一致し た。よって, 用いたアガロースは, 脳組織の力学的なモデ ルとして適切であると考える。

電気生理実験では，電極アレイをラット聴皮質に刺入し， 発火電位の多点同時計測と皮質への繰り返し刺入が可能な ことを示した。神経信号増幅記録装置 (Cyberkinetics Inc., Cerebus) を用いて， 0.75-7.5 kHzのバンドパスフィルタを通 して 5000 倍に増幅した計測電位から, 音刺激で誘発される 発火電位を抽出し，その発火時間を記録した。さらに，刺 入部位の神経反応の特徵を抽出するために, 各電極で計測 された発火電位にもとづいて, 各電極周辺の周波数閾值曲 線を求め, 特徵周波数を推定した。ペントバルビタール麻 酔下 $(50 \mathrm{mg} / \mathrm{kg})$ のラット聴皮質に, 油圧式マイクロマニピ ユレータ（ナリシゲ, MO-10）を用いて電極アレイを硬膜上 から刺入した。その際, 実体顕微鏡でゴム基板が脳表に密 着したことを確認した。刺激音はラットから $10 \mathrm{~cm}$ 離して 設置したスピーカ（松下電器産業，10TH800）から提示した。 刺激音には, 周波数を $5-50 \mathrm{kHz}$, 音圧を 30-90 dBSPL, 立ち 上がり・立ち下り時間・プラトーをそれぞれ $5 \mathrm{~ms}$ としたト ーンバースト音を用い，200 ms 間隔で無作為に与えた。刺 激音の音圧は，スピーカから $10 \mathrm{~cm}$ の位置に設置したマイ クロホン (Bruel\&Kjaer, 4939) を用いてあらかじめ校正し た。なお，用いた電極アレイは，一次聴覚野の大きさを考 (a)

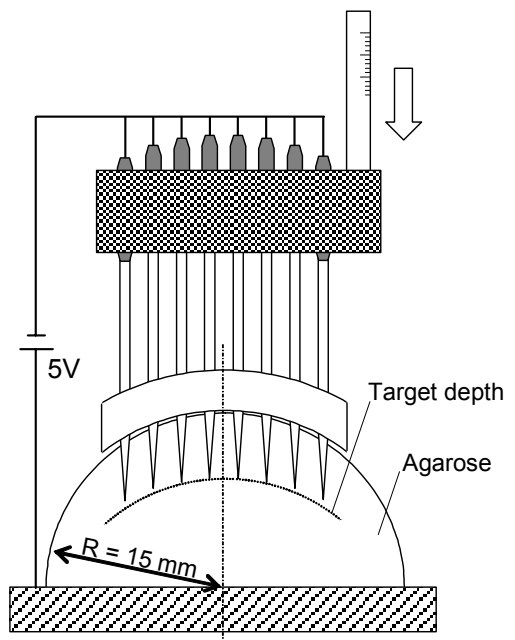

(b)

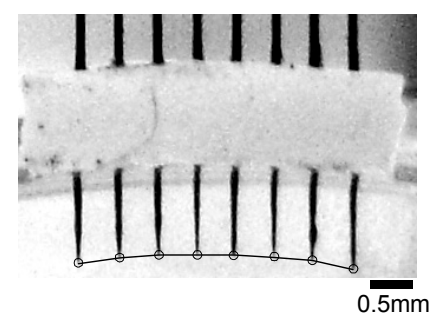

(c)

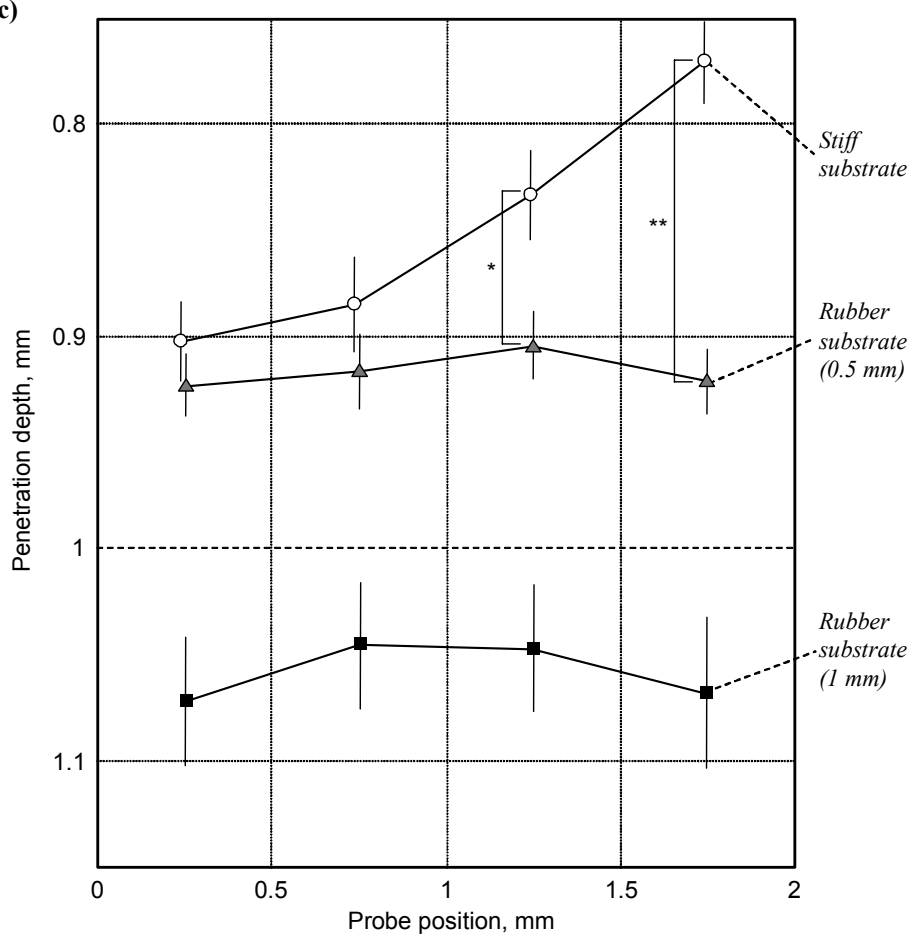

(a) Experimental setup. (b) Electrode tips of the array inserted into agarose. (c) Penetration depth of each electrode. Means and standard errors are plotted with respect to each kind of substrate against the electrode positions with a center of array as origin. *, $\mathrm{p}<0.05 ; * *, \mathrm{p}<0.01 ; \mathrm{t}$-test.

Fig. 5. Penetration experiment into agarose $(\mathrm{n}=18)$ 

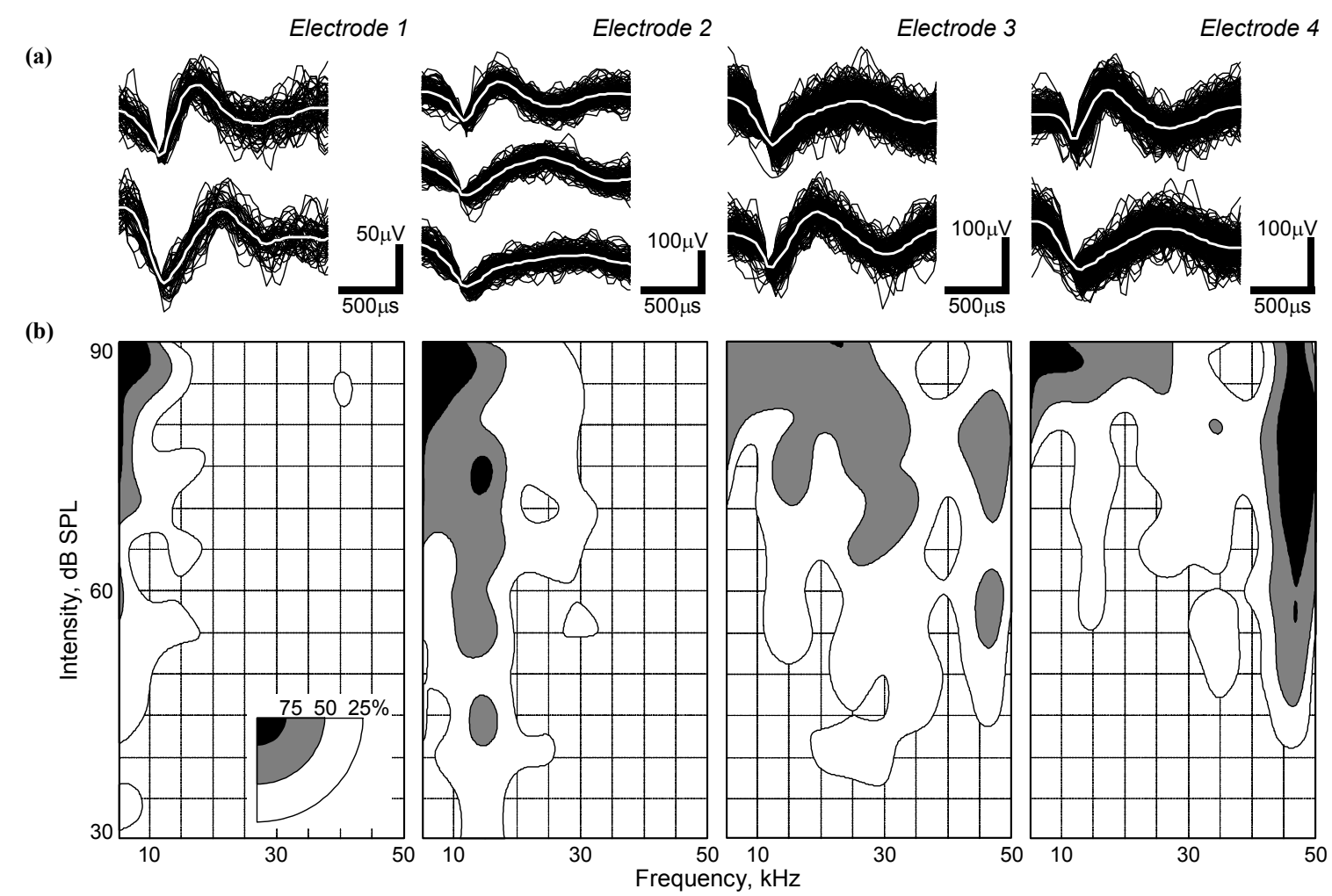

(a) Sorted single-unit spike potentials. White bold lines show averaged traces. (b) Firing rate for each test tone. Three contour lines indicate 75,50 and $25 \%$ of the maximum spiking rate.

Fig. 6. Tone-evoked neural responses

慮して ${ }^{(15)}$, 電極間隔を $500 \mu \mathrm{m}$, 電極本数を 4 本とした。

なお，本実験は，東京大学動物実験マニュアルに則して 実施した。

〈3.2〉 結 果 図 5(b) に基板幅 $0.5 \mathrm{~mm}$ の電極ア レイをアガロースに刺入した様子を示す。アガロースの曲 面に沿って基板が変形し, 刺入深さが一定に保たれている ことがわかる。図 5(c) に各電極の刺入深さを, アレイ中心 からの距離に対して示した。ゴム基板アレイでは，基板幅 が 0.5, $1 \mathrm{~mm}$ のアレイ双方で, 各電極の刺入深さが一定に 保たれたことがわかる (ANOVA; $0.5 \mathrm{~mm}, \mathrm{p}=0.835 ; 1 \mathrm{~mm}$, $\mathrm{p}=0.904 ; \mathrm{n}=18)$ 。刺入深さの平均はそれぞれ $0.92,1.06 \mathrm{~mm}$ だった。また, 各試行での刺入深さの最大值と最小值の差 を刺入深さのばらつきとして定義すると，その平均はそれ ぞれ 44, $67 \mu \mathrm{m}$ だった。固定アレイでは, 電極間の刺入深 さに有意な差が見られ (ANOVA, $\mathrm{p}<0.01)$, 試行ごとのばら つきの平均は $139 \mu \mathrm{m}$ だった。同アレイでは，端部の電極の 刺入深さにゴム基板アレイ（幅 $0.5 \mathrm{~mm}$ ）のそれと比べて有 意な差が見られ（ $\mathrm{t}$ 検定; $\mathrm{p}<0.01)$ ，その差は平均で約 $150 \mu \mathrm{m}$ だった。

電気生理実験では，ラット聴皮質に刺入した電極アレイ の 4 本の電極全てから, 音刺激で誘発された神経細胞の発 火電位を計測できた。図6(a) に各電極で得られた発火電位 波形を, 主成分分析で分類した単一ユニット毎 ${ }^{(5)}$ に示す。図 6(b) は, 刺激音の周波数を横軸に, 音圧を縦軸にとり, 各
刺激音で誘発された発火電位の頻度を, 最大值を $100 \%$ とし て等高線で示している。25\%の等高線を, 各電極周辺部位 の周波数閾值曲線とみなして ${ }^{(16)}$, 特徵周波数を推定すると, 尾側から吻側にかけてそれぞれ $5 \mathrm{kHz}, 15 \mathrm{kHz}, 30 \mathrm{kHz}, 45$ $\mathrm{kHz}$ であった。一次聴覚野には吻尾方向に周波数軸が存在す ることが知られており ${ }^{(17)(18)}$, 本アレイを用いて一次聴覚野 を同定し，4 本の電極全てをそこに設置できたと考える。同 定完了に必要な刺入回数は 6 回であり, その間, 発火電位 は全ての電極から安定して記録された。

\section{4. 考察}

図 5(c) に示したように，本電極アレイでは，曲率を有す るアガロースの表面形状に追従してゴム基板が変形し，各 電極の刺入深さがほぼ一定に保たれた。刺入深さの電極間 のばらつきは平均で $44 \mu \mathrm{m}$ と, 固定アレイの $139 \mu \mathrm{m}$ と比較 して，十分に小さく抑えられた。ラットやマウスの新皮質 では，層の厚みが $200 \mu \mathrm{m}$ 以下である場合も多く(1)(3),(19)， ア レイの各電極を一定の深さに刺入し, 所望の層から神経反 応を計測するには，柔軟な基板を有する本電極アレイが有 用であると考える。

しかし，ゴム基板幅 $0.5,1 \mathrm{~mm}$ のアレイそれぞれの刺入 深さにも, 設計值の $1 \mathrm{~mm}$ と比較して平均 $-80,+60 \mu \mathrm{m} の$ 誤差が生じた。この誤差の要因には, i) 先端仕上げの工程 で電極先端の一部を除去するため, 電極の長さ自体が設計 
值の $1 \mathrm{~mm}$ よりも短くなり，刺入深さが不足した，ii）基板 をアガロース表面に沿って変形させる時に，アガロースも 押し込まれて弾性変形し, 刺入深さが電極の長さを超えた, という 2 点が考えられる。前者は基板幅 $0.5 \mathrm{~mm}$ のアレイで 顕著であるが，先端の除去分を見込んでアセンブリ型を設 計することで容易に解決できると考える。一方, 基板幅 $1 \mathrm{~mm}$ のアレイでは後者の要因が顕著に見られた。基板を変形さ せるために必要な荷重が増え，アレイを押し付けたときに 生じるアガロースの変形が，刺入深さに比べて無視できな い大きさになったことがわかる。基板の柔軟性を高めるた めには, 基板厚・幅を減じることが有効だが, 基板厚を $1 \mathrm{~mm}$ 以下にすると電極の保持力が著しく悪化した。一方, 基板 幅は電極の保持に大きな影響を与えなかったため，実用上 可能な限り薄く設定することが有用であると考える。

これまでにも，柔軟な素材として，ポリイミドフィルム を基板に用いた電極アレイが提案されてきた(10)(11)。しかし， これらの電極アレイは，ピンセット等を用いて手作業で刺 入されるため，正確な刺入部位の位置決めが困難だった。 本アレイは，アレイ両端の電極のみを把持することで，基 板の柔軟性を保ったままマイクロマニピュレータに取り付 けられる。そのため本アレイは，ラット聴皮質での電気生 理実験で示したように，正確に位置決めした刺入を繰り返 しながら各部位で神経反応の特徴抽出を行い，特定の領野 を探索・同定する必要があるような急性実験に適している と考える。ただし，マニピュレータへの取付けを優先した ため，配列が一列に限定されており，2 次元アレイとして用 いることは困難である。また，アレイ両端の電極のみを固 定して刺入するため，凹曲面への刺入も難しい。これらは， ホルダの形状等を改良することで実現できる可能性もあ り，今後の開発の課題である。

\section{5. おわりに}

本研究では, 基板が脳表の曲率に追従して変形し, 各電 極の刺入深さを一定に保つことができる刺入形電極アレイ を設計・試作した。アレイは，柔軟なシリコーンゴム基板 とそれに保持された微小タングステン電極から成る。アガ ロースを用いた刺入実験で，本電極アレイの電極間の刺入 深さのばらつきが，固定アレイのそれと比べておよそ三分 の一に抑えられていることを示した。また，試作したアレ イをラット聴皮質で試用したところ，マイクロマニピュレ 一タを用いて正確に位置決めをしながら，硬膜上から刺入 できた。さらに，音刺激で誘発される発火電位を多点同時 計測し, 硬膜上からの刺入を繰り返すことで, 一次聴皮質 を同定できた。これは，本アレイが，従来の柔軟電極アレ イと比較して, 繰り返しの刺入や正確な位置決めが必要な 急性実験に適していることを示している。

なお, 本研究の一部は, 科学研究費補助金若手研究 $\mathrm{A}$ (16686014) の助成を受けて実施した。

(平成 19 年 1 月 26 日受付，平成 19 年 6 月 12 日再受付)

\section{文献}

(1) DH. Hubel and TN. Wiesel : "Laminar and columnar distribution of Geniculo-cortical fibers in the macaque monkey", J. Comp. Neurol, Vol.146, pp.421-450 (1972)

(2) DS. Barth and S. Di : "Three-dimensional analysis of auditory-evoked potentials in rat neocortex", J. Neurophysiol., Vol.64, pp.1527-1536 (1990)

(3) S. Sugimoto, M. Sakurada, J. Horikawa, and I. Taniguchi : "The columnar and layer-specific response properties of neurons in the primary auditory cortex of Mongolian gerbils", Hear. Res., Vol.112, pp.175-185 (1997)

(4) PE. Maldonado and GL. Gerstein : "Reorganization in the auditory cortex of the rat induced by intracortical microstimulation: a multiple single-unit study", Exp. Brain Res., Vol.112, pp.420-430 (1996)

(5) MAL. Nicolelis, AA. Ghazanfar, BM. Faggin, S. Votaw, and LMO. Oliveira : "Reconstructing the engram: simultaneous, multisite, many single neuron recordings", Neuron, Vol.18, pp.529-537 (1997)

(6) H. Takahashi, M. Nakao, and K. Kaga : "Distributed representation of sound intensity in the rat auditory cortex", Neuroreport, Vol.15, pp.2061-2065 (2004)

( 7 ) PK. Campbell, KE. Jones, RJ. Huber, KW. Horch, and RA. Normann : "A silicon-based, three-dimensional neural interface: manufacturing processes for an intracortical electrode array", IEEE Trans. Biomed. Eng., Vol.38, pp.758-768 (1991)

(8) AJ. Verloop and J. Holsheimer : "A simple method for the construction of electrode array", J. Neurosci. Methods, Vol.11, pp.173-178 (1984)

(9) MAL. Nicolelis, D. Dimitrov, JM. Carmena, R. Crist, G. Lehew, JD. Kralik, and SP. Wise : "Chronic, multisite, multielectrode recordings in macaque monkeys", Proc. Natl. Acad. Sci. USA, Vol.100, pp.11041-11046 (2003)

(10) 赤松直樹・鈴木隆文・満渕邦彦・藤田博之・金 範讼- 竹内昌治:「神 経電位計測用フレキシブルシリコンプローブアレイ」, 電学論 E, 123, pp.571-576 (2003)

(11) S. Takeuchi, T. Suzuki, K. Mabuchi, and H. Fujita : "3D flexible multichannel neural probe array", $J$ Micromech. Microeng., Vol.14, pp.104-107 (2004)

(12) DH. Hubel : "Tungsten microelectrode for recording from single units", Science, Vol.125, pp.549-550 (1957)

(13) JD. Green : "A simple microelectrode for recording from the central nervous system", Nature, Vol.182, p.962 (1958)

(14) H. Takahashi, J. Suzurikawa, M. Nakao, F. Mase, and K. Kaga "Easy-to-prepare assembly array of tungsten microelectrodes", IEEE Trans. Biomed. Eng., Vol.52, pp.952-956 (2005)

(15) NN. Doron, JE. Ledoux, and MN. Semple : "Redefining the tonotopic core of rat auditory cortex: Physiological evidence for a posterior field", $J$. Comp. Neurol., Vol.453, pp.345-360 (2002)

(16) JJ. Eggermont : "How homogeneous is cat primary auditory cortex? Evidence from simultaneous single-unit recordings", Audit. Neurosci., Vol.2, pp.79-96 (1996)

(17) SL. Sally and JB. Kelly : "Organization of auditory cortex in the albino rat: sound frequency", J. Neurophysiol., Vol.59, pp.1627-1638 (1988)

(18) MP. Kilgard and MM. Merzenich : "Distributed representation of spectral and temporal information in rat primary auditory cortex", Hear. Res., Vol.134, pp.16-28 (1999)

(19) V. Braitenberg and A. Schuz : "Anatomy of the Cortex -Statistics and Geometry-", Springer-Verlag (1991)

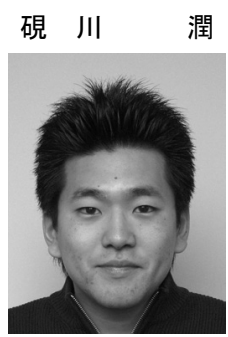

（非会員） 1981 年 8 月 15 日生。 2006 年東京大 学大学院工学系研究科 (産業機械工学専攻) 修 士課程を修了。現在, 東京大学大学院情報理工 学系研究科（知能機械情報学専攻）博士課程に 在学中。神経工学, 生体電子工学の研究に従事。 IEEE 会員。 
中 尾 政 之 (正員) 1958 年 9 月 24 日生。1 983 年東京大

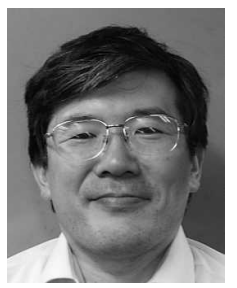
学大学院工学系研究科（機械工学専攻）修士課 程を修了。同年日立金属（株）に入社。1989 年から HMT Technology Corp.に出向。1992 年東 京大学大学院工学系研究科（産業機械工学専 攻）助教授として赴任。2001 年東京大学工学部 附属総合試験機構教授, 2006 年より東京大学大 学院工学系研究科 (産業機械工学専攻) 教授。 創造設計のためのナレッジマネージメント, ナノ・マイクロ加工, および超精密加工とその産業界への応用に従事。
高橋宏 知 (正員) 1975 年 7 月 19 日生。 2003 年東京大 学大学院工学系研究科 (産業機械工学専攻) 博 士課程を修了。同年, 東京大学大学院工学系研 究科（産業機械工学専攻）助手, 2004 年, 同情 報理工学系研究科（知能機械情報学専攻）講師 を経て, 2006 年より東京大学先端科学技術研究 センター講師。福祉工学, 感覚代行デバイスの 開発, 聴覚生理学など, 医学・工学の境界領域 の研究に従事。生体医工学会, 電気学会等会員。博士 (工学)。 